dzynarodowej literaturze przedmiotu monografii H. Pietrasa - L'amore in Origene (Roma 1988).

Na zakończenie wypada pochwalić stronę edytorską prezentowanej książki. Teksty greckie podane są w większości czcionką oryginalną i, co najważniejsze, nie roją się od błędów, co, niestety, zdarza się w rodzimych publikacjach, mimo wciąż postępującej komputeryzacji. Dokładne indeksy (biblijny, dzieł Orygenesa, autorów starożytnych i współczesnych) ułatwiają poruszanie się po opasłym tomie i umożliwiają pełne wykorzystanie zawartych w nim informacji. Pozostaje mi tylko zachęcić do zapoznania się z aktualnym stanem badań nad Orygenesem, a zwłaszcza nad orygenizmem ${ }^{5}$. Trzeba to zrobić jak najszybciej, ponieważ już w roku 2001 następne „Colloquium Origenianum Octavum” odbędzie się tym razem w Pizie, pod kierownictwem L. Perone.

$$
\text { Ks. Mariusz Szram - Lublin }
$$

\title{
Giovanni REALE, Historia filozofii starożytnej. Tom IV: Szkoły epoki cesarstwa, przełożył Edward Iwo Zieliński, Lublin 1999, RW KUL, ss. 696 + mapka.
}

Niniejszy tom, który swoim zakresem obejmuje dzieje grecko-rzymskiej myśli filozoficznej, tworzonej w środowisku pogańskim od pierwszego wieku przed Chrystusem (umownie: od 31 r., czyli od bitwy pod Akcjum), aż do jej końca na pocz. VI w. ery chrześcijańskiej (znowu symbolicznie: do roku 529, czyli zamknięcia neoplatońskiej Akademii przez cesarza Justyniana), doprowadza do kresu część historyczną syntezy Giovanniego Reale, poświęconej filozofii starożytnej. Tłumaczenia poprzednich tomów ukazywały się w tym samym wydawnictwie, również w przekładzie o. Zielińskiego, od roku 1993; a mianowicie tom I: Od początków do Sokratesa w roku 1993, tom II: Platon i Arystoteles w roku 1996, wreszcie tom III: Systemy epoki hellenistycznej w roku 1999. Oczekiwany jest jeszcze tom V, który będzie miał charakter systematyczny i będzie zawierał słownik terminów filozoficznych myśli starożytnej, będący zarazem indeksem rzeczowym do wszystkich poprzednich tomów, słownik biograficzny filozofów, uwzględniający również hasła dotyczące szkół filozoficznych oraz najważniejsze informacje bibliograficzne dotyczące danego myśliciela i danej szkoły, oraz indeks osobowy. Biorąc pod uwagę ogromną obfitość zarówno materiału faktograficznego, jak i problemowego zawartą w pracy, tom $\mathrm{V}$ będzie nieodzownym uzupełnieniem części historycz-

${ }^{5} \mathrm{~W}$ języku polskim nadal chyba jedyną publikacją dotyczącą sporów orygenesowskich pozostaje syntetyczny i przekrojowy artykuł S. Longosza, Orygenizm i spory wokót Orygenesa, VoxP 5(1985) z. 8-9, 395-412. 
nej opracowania profesora Reale, która jest już w całości dostępna w języku polskim.

Autor, profesor Uniwersytetu Katolickiego Sacro Cuore w Mediolanie, jest badaczem starożytności o niezwykle rozległych zainteresowaniach. Opublikował już szesnaście prac monograficznych, dotyczących takich tematów jak: filozofia Arystotelesa, a szczególnie jego Metafizyka, metafizyka Teofrasta, filozofia Proklosa, starożytne koncepcje człowieka, przede wszystkim jednak przedmiotem jego badań jest Platon. Reale dał się poznać jako zwolennik interpretacji myśli Platona, opracowanej w latach sześćdziesiątych na uniwersytecie w Tybindze przez H. Kraemera i K. Gaisera, szukającej klucza do rozumienia nauki wielkiego Ateńczyka w tzw. naukach niepisanych, których Platon nie zawarł w dialogach i które można zrekonstruować na podstawie tradycji pośredniej, głównie relacji Arystotelesa w I księdze Metafizyki.W tym też duchu napisana jest jego monografia: Per una nuova interpretazione di Platone. Rilettura della metafisica dei grandi dialoghi alla luce delle „Dottrine non scritte" (ed. XX, Milano 1997, Vita e Pensiero). Pozycja ta została przethumaczona na angielski, niemiecki i portugalski. Reale przetłumaczył też na język włoski i wydał z komentarzem dwanaście dialogów Platona, fragmenty Melissosa i Parmenidesa, Metafizykę Arystotelesa, O naturze dobra św. Augustyna, opracował wydania tłumaczeń Filona, Seneki, Epikteta i Proklosa. Jego Storia della filosofia antica w pięciu tomach, która jest podstawą omawianego tłumaczenia, ukazała się po raz pierwszy w latach 1975-1980 w wydawnictwie Vita e Pensiero w Mediolanie. W roku 1992 miała już swoje dziesiąte wydanie i przetłumaczona została na język angielski i portugalski.

Czytelnik, znający zapewne klasyczne już na gruncie polskim opracowanie dziejów filozofii starożytnej w I tomie Historii filozofii Władysława Tatarkiewicza, jak również syntezy B. Fullera, A. Krokiewicza, J. Legowicza i niedawno opublikowany (Warszawa 1998, IW PAX) pierwszy tom Historii filozofii Coplestona, może zadać pytanie, czy potrzebne jest na rynku polskim jeszcze jedno całościowe ujęcie tematu tak już wielokrotnie opracowywanego. Wydaje się, że nawet powierzchowne zetknięcie się z książką profesora Realego może uświadomić, że tego typu synteza jest czymś w dużym stopniu nowym w naszej literaturze. Wystarczy choćby porównać objętość omawianego tomu z objętością tekstu poświęconego tym samym zagadnieniom u Tatarkiewicza (s. 159-172 we wznowieniu z r. 1999) i u Coplestona (s. 482-567). W odróżnieniu od tych autorów, którzy są przede wszystkim filozofami i patrzą z perspektywy uniwersalnej problematyki filozoficznej, pomijając zatem zagadnienia bardziej szczegółowe, Reale jest przede wszystkim historykiem myśli starożytnej, który stara się pokazać, w jakich konkretnych, historycznie określonych formach pojawia się i rozwija myśl filozoficzna. Tak więc zamiast wysoce syntetycznych formuł, podanych w abstrakcyjnym języku technicznym, Reale stara się przede wszystkim pokazać kontekst zarówno społeczny, jak i intelektualny, warunku- 
jący wystąpienie danego faktu historyczno-filozoficznego, jak również konkretny kształt językowy, w jakim myśl danego myśliciela czy danej szkoły znalazła swój wyraz. Stąd też interesują go nie tylko fakty wagi pierwszorzędnej, postaci pierwszej wielkości i sformułowania klasyczne, ale również myśliciele i teksty mało znane i często pomijane jako rzekomo nie wnoszące niczego istotnego, a nawet fakty z pogranicza filozofii i innych dziedzin kultury, które przecież jednak współtworzyły klimat intelektualny, w jakim mogło wzrastać i kształtować się to, co my, z perspektywy czasu, uznajemy za ważne. Tak więc, oprócz zwięzłych formuł i definicji, właściwych dla syntezy historyczno-filozoficznej, otrzymujemy niezwykle bogatą panoramę szczegółów, postaci i wypowiedzi mało lub w ogóle nieznanych, możemy niejako śledzić, w jaki sposób z tego bogactwa konkretu wyłaniają się stopniowo istotne zarysy doktryn i faktów historycznych, znanych z opracowań encyklopedycznych. To bogactwo konkretnych odniesień stanowi chyba o specyfice, niepowtarzalności, a także, jak sądzę, o pewnym uroku książki Realego, choć z drugiej strony może również przytłaczać. Z tego właśnie względu skorowidze, które znajdą się w tomie V, będą zapewne stanowić niezbędną pomoc przy lekturze.

Z zakresu omawianego tomu autor celowo wyłącza myśl Ojców Kościoła, gdyż uważa, że stanowi ona raczej wstęp do myśli średniowiecza niż ukoronowanie myśli klasycznej (s. 618), ale mimo to obejmuje on bez mała sześć wieków bogatych w spekulację filozoficzną. Całość podzielona jest na trzy części i poprzedzona uwagami wstępnymi. Część pierwsza (s. 27-261) omawia końcową fazę oraz upadek szkoły perypatetyckiej i wielkich szkół hellenistycznych, w związku z tym część ta podzielona została na pięć sekcji, a każda z nich poświęcona innej szkole. Omawiając dzieje Perypatu (s. 29-72), autor zwraca uwagę na losy spuścizny piśmienniczej Stagiryty, utratę dla szkoły pism ezoterycznych oraz ich odzyskanie i ponowne wydanie przez Andronika z Rodos w I wieku przed Chrystusem, krótko omawia znanych scholarchów Likeionu i innych perypatetyków działających po Stratonie, przede wszystkim jednak zwraca uwagę na myśl Aleksandra z Afrodyzji i daje interpretację tej myśli polemiczną w stosunku do tradycyjnego ujęcia, wywodzącego się od E. Zellera w jego klasycznym dziele Die Philosophie der Griechen (Lipsk 1919).

Sekcja druga (s. 73-91) poświęcona jest końcowi szkoły epikurejskiej; postacią zasługującą na więcej uwagi jest tutaj Diogenes z Ojnoandy i jego portyk z wyrytą w kamieniu nauką Epikura (s. 84-89). Sekcja trzecia (s. 93-170) omawia odrodzenie stoicyzmu w Rzymie. Oprócz klasycznych postaci neostoicyzmu, takich jak Seneka (s. 100-111), Epiktet (s. 127-148) i Marek Aureliusz (s. 149166), w osobnym rozdziale omówiony jest Muzoniusz Rufus (s. 120-126).

Odrodzony pirronizm i neosceptycyzm są przedmiotem sekcji czwartej (s. 171-230). Bardzo wnikliwie i pouczająco ukazana jest tu ewolucja poglądów sceptyckich od Ajnezydema (s. 173-200), poprzez Agryppę (s. 204-208), lekarzy empiryków i Menodota (s. 209-215) do Sekstusa Empiryka (s. 209-227). 
Stosunkowo mało znane a bardzo interesujące odrodzenie się szkoły cynickiej w epoce cesarstwa jest przedmiotem sekcji piątej (s. 231-261), z takimi filozofami, jak Demetrios, Dion z Prusy, Ojnomaos z Gadary, Demonaks i Peregrinos Proteus.

Część II (s. 263-466) poświęcona jest odrodzeniu platonizmu i pitagoreizmu począwszy od I w. przed Chrystusem. Jest to temat bliski autorowi, dla którego, jak czytelnicy II i III tomu omawianej Historii wiedzą, ukoronowaniem i najwyższym osiągnięciem antycznej spekulacji filozoficznej jest ujęcie rzeczywistości w perspektywie bytu transcendentnego, które ma miejsce na terenie metafizyki. Odkrywcą tej perspektywy był oczywiście Platon, od którego Reale bierze metaforyczne określenie spekulacji metafizycznej jako „drugiego żeglowania" (por. t. II, s. 78 nn.). Odkrycie to kontynuował w swojej teorii metafizycznej Arystoteles, zostało ono jednak zapoznane bądź nawet celowo odrzucone w epoce hellenistycznej (por. t. III, s. 30), która przeszła na pozycje materializmu, nie wyłączając nawet szkół założonych przez samego Platona i Arystotelesa. Właśnie I wiek przed Chrystusem, a dokładniej jego druga połowa, jest świadkiem odzyskania perspektywy metafizycznej za sprawą środowiska aleksandryjskiego, gdzie odradza się platonizm w postaci średniego platonizmu lub według określenia Realego, „medioplatonizmu”, a przede wszystkim w myśli przedstawiciela zhellenizowanej diaspory żydowskiej - Filona z Aleksandrii. Filonowi poświęca autor całą sekcję pierwszą (s. 265-322), podkreślając jego przełomową rolę jako tego, który pierwszy przeprowadził syntezę filozofii greckiej z tradycją Objawienia żydowskiego (s. 267-279), pierwszy postawił pytanie o relację między wiarą a rozumem (s. 280-284), pod wpływem biblijnej koncepcji Boga wprowadził do myśli hellenistycznej nowe, nieznane nawet Platonowi, rozumienie transcendencji (s. 294nn.), które wywarło silny wpływ na rozumienie najwyższej zasady w medio- i neoplatonizmie, zmodyfikował platońską naukę o ideach interpretując je jako archetypy świata stworzone przez Boga w Jego akcie myślenia (s. 307), poprzez swoją koncepcję logosu wywarł wpływ na rozumienie świata inteligibilnego w późniejszej myśli filozoficznej, wreszcie w sposób nowatorski pojął człowieka (złożenie z ciała, duszy i Ducha) i jego ostateczny cel, którym jest ekstatyczne zjednoczenie z Bogiem (s. 311-322). Nie zapomina autor również o prekursorskiej roli Filona względem myśli chrześcijańskiej (s. 270, 280), dzięki swojej koncepcji alegorezy biblijnej (s. 278), dzięki postawieniu i rozwiązaniu zagadnienia relacji Objawienia i rozumu filozoficznego (s. 280-284), czy dzięki nowemu rozumieniu transcendencji Boga i Jego relacji do świata (s. 290-301).

Sekcje druga (s. 323-377) i trzecia (s. 379-437) poświęcone są odpowiednio medioplatonizmowi i pitagoreizmowi po epoce klasycznej. Oba nurty ukazane zostały w podobnej perspektywie: autor widzi w nich przede wszystkim spekulację odzyskującą wyniki platońskiego „drugiego żeglowania”, gdzie powraca rozumienie bytu jako rzeczywistości niecielesnej, a materializm stoicyzmu 
i epikureizmu zostaje zastąpiony przez kosmogonię i kosmologię platońskiego Timajosa. W nurcie medioplatońskim (Trasyllos, Plutarch z Cheronei, Gaios, Albinos, Apulejusz, Attikos, Teon ze Smyrny i inni) dokonuje się modyfikacja pojmowania platońskich idei, przedstawiona jako owoc syntezy nauki Platona o tym, co niecielesne jako przedmiocie myśli (idee) oraz teologii Arystotelesa, który byt transcendentny pojął jako umysł, jako myśl myślącą siebie (s. 352). Odtąd (być może nie bez wpływu Filona) byt transcendentny rozumiany będzie jako boski intelekt, którego wieczne i niezmienne myśli są tym, co Platon nazwał ideami (s. 351-355). Również w tymże nurcie kształtuje się wizja rzeczywistości jako hierarchii różnych postaci boskiego bytu (Bóg-Jedno, umysł, dusza), która wyraźnie zapowiada hipostazy Plotyna (s. 355-359). Neopitagorejczycy, w swojej koncepcji bytu transcendentnego, nawiązują przede wszystkim do nauki o Monadzie i nieograniczonej Diadzie oraz o liczbach idealnych, którą autor, w zgodzie z tezami szkoły tybińskiej, wywodzi z ezoterycznego nauczania Platona w Akademii (s. 411-415). W nurcie neopitagorejskim szczególnie wyeksponowana jest postać Numeniosa z Apamei (s. 422-437), przedstawionego jako autora najdalej idącej syntezy, utrzymanej w duchu platońskim przed Plotynem; wyakcentowana jest też prekursorska pozycja Numeniosa względem twórcy neoplatonizmu (triada bóstw zapowiadająca triadę hipostaz, koncepcja pochodzenia bliska emanatyzmowi, twórcza rola kontemplacji, mistyczny ideał życia ludzkiego).

Czwarta sekcja (s. 439-466) II części omawia zjawiska z pogranicza filozofii oraz religii i teozofii, jakimi są starożytna literatura hermetyczna i nauki tajemne oraz „Wyrocznie Chaldejskie” i związane z nimi praktyki magiczne i teurgiczne. Autor uzasadnia włączenie tego rozdziału do historii filozofii rolą, jaką mentalność przez nie reprezentowana odegrała w ukształtowaniu się zwłaszcza późniejszych etapów neoplatonizmu (s. 465-466). Omówienie to jest krótkie, ale bardzo wnikliwe i ukazujące ważne odniesienia.

Część III (s. 467-692) dotyczy, rzecz jasna, najbardziej interesującego rozdziału dziejów filozofii w epoce cesarstwa, jakim jest niewątpliwie filozofia neoplatońska. Sekcja pierwsza (s. 469-508) poświęcona jest historycznym okolicznościom wystąpienia twórcy Ennead, jego biografii, jego relacji do poprzedników, w szczególności Ammoniosa Sakkasa (s. 471-480), jego stosunkowi do Platona oraz różnym interpretacjom jego myśli zaproponowanym przez historyków filozofii. Sekcja druga (s. 509-613), najdłuższa w całym tomie, stanowi obszerną prezentację systemu Plotyna, poczynając od absolutu-Jedni (s. 511531 ), poprzez relację pochodzenia (autor celowo unika terminu „emanacja”, por. s. 604-605) wiąząąą Jedno z dalszymi hipostazami (s. 525-535), następnie przez hipostazę Umysłu (s. 532-546), Duszy (s. 547-559) aż po materię (s. 561566) i kosmos fizyczny (s. 560-573) oraz człowieka (s. 574-603), jego pochodzenie (s. 574-578), naturę i ostateczny cel (s. 587-603). Autor zaprasza nas do uważnego podążania za wzniosłą, ale niełatwą i miejscami zawiłą oraz niejasną 
myślą filozofa. Ograniczmy się do tego, co czytelnika znającego standardowe opracowania podręcznikowe i encyklopedyczne może uderzyć jako nowe i, być może, kontrowersyjne. Autor podkreśla i obszernie cytuje te teksty Plotyna, gdzie ukazany jest wolny i dynamiczny charakter absolutu-Jedni; Jedno jest samostwarzającą się aktywnością, jest causa sui, jest tym czym jest, ponieważ chce siebie samego (ss. 523n., 607n.). Jego byt jest działaniem wewnętrznym, dynamicznym podtrzymywaniem siebie samego w istnieniu (s. 530). Ta właśnie aktywność, niejako ad intra, generuje aktywność skierowaną na zewnątrz, tradycyjnie określaną emanacją (s. 531). Reale proponuje, w oparciu o cytaty z Ennead, gruntowną reinterpretację emanacjonistycznego rozumienia koncepcji Plotyna, sam zaś termin zastępuje terminem, który tłumacz oddaje słowem ,pochodzenie”. Po pierwsze, emanacja tradycyjnie rozumiana jest jako proces konieczny, tymczasem Plotyn wydaje się wskazywać moment wolności w aktywności Jednego: Jedno chce być tym, czym jest. Konsekwentnie również i ,...działanie, które pochodzi od Jednego, a które koniecznie następuje za działaniem Jednego (czyli domniemana emanacja), jest koniecznościa w pewnym sensie chciana, to znaczy [... ...] konsekwencja aktu wolnego."(s. 531). Zatem w wyprowadzeniu świata z Jednego, istotną rolę odgrywa moment wolności, chociaż istnieje tu również moment konieczności. Po drugie, przy wyprowadzeniu kolejnych hipostaz, istotną rolę odgrywa moment nazwany „stwórczą kontemplacją". Tym, co Jedno wyłania z siebie, jest nieokreślona „materia inteligibilna” (s. 532), nieokreślona myśl (s. 533) i dopiero kontemplatywne zwrócenie się do Jednego tworzy z owej „materii” Umysł. Podobny schemat trzech typów działania (refleksyjna aktywność wyższej zasady, produktywna aktywność tejże skierowana na zewnątrz, kontemplatywna aktywność niższej hipostazy w stosunku do wyższej, nadająca formę niższej hipostazie) powtarza się przy wyprowadzeniu innych stopni bytu (np. s. 547-549). Właśnie kontemplacja dostarcza całej energii twórczej rzeczywistości Plotyna: do niej w istocie sprowadza się całe działanie bytu, a także praxis ludzka (s. 610-613, w szczególności cytat na s. 612). Ten wniosek, podobnie jak i wskazanie na moment wolności w trwaniu Jednego, wydaje się $\mathrm{w}$ istotny sposób modyfikować rozumienie myśli autora Ennead.

Ostatnia sekcja (s. 615-692) omawia dzieje neoplatonizmu po Plotynie. I tutaj autor odchodzi od tradycyjnego ujęcia pochodzącego od Zellera, a znanego z podręcznika Tatarkiewicza, wyróżniając sześć, wliczając szkołę Ammoniosa Sakkasa, szkół neoplatonizmu, a nie trzy. Jeden rozdział omawia bezpośrednich uczniów Plotyna, Ameliusza i Porfiriusza (s. 623-633). Ukazany jest system hipostaz, klasyfikacja cnót oraz krytyka praktyk teurgicznych tego ostatniego. Jamblich i szkoła syryjska (s. 634-649) ukazani są jako odpowiedzialni za zwrot w kierunku apologii tradycyjnego politeizmu i tychże praktyk teurgicznych, charakterystycznych dla późnego neoplatonizmu, ukazane są systemy hipostaz Jamblicha i Teodora z Assiny. Szkoła pergamońska (s. 650- 
655), z którą związany był cesarz Julian Apostata, tylko pogłębiła tendencje magiczne i irracjonalistyczne, zapoczątkowane przez szkołę syryjską. Szkoła ateńska (s. 656-679), wydała jednego wybitnego myśliciela, którym był Proklos (s. 660-677); omówione zostają jego skomplikowany system hipostaz i koncepcja trzech faz procesu powstawania rzeczy (monē, proodos, epistrofē). Wreszcie druga szkoła aleksandryjska (s. 680-685) oraz myśliciele działający na łacińskim Zachodzie świadczą ostatecznie o wyczerpaniu energii spekulatywnych pogańskiego neoplatonizmu, myśliciele tej szkoły ograniczają się do komentowania dorobku przeszłości, wytwarzają typ kultury erudycyjnej i encyklopedycznej, ważnej nie ze względu na własne oryginalne osiągnięcia, ale ze względu na to, że przekazuje ona epoce następnej wartości wypracowane przez starożytność pogańską. Jak pięknie pisze autor: „ «Drugie żeglowanie» zakończyło się już dawno, a rozpoczęło się [... ...] to, co można by nazwać «trzecim żeglowaniem», tzn. kulturą umysłową, rozwijaną w oparciu o orędzie chrześcijańskie" (s. 691). Jak pieczęć zamyka tom IV krótki rozdział dotyczący edyktu Justyniana i losów neoplatoników ateńskich, podróżujących do Persji na dwór Chosroesa (s. 688-692).

Wypada zaznaczyć, że przy cytatach ze starożytnych źródeł i tekstów filozoficznych, którymi autor często i obszernie dokumentuje swoje wywody, Tłumacz posłużył się istniejącymi przekładami na język polski, o ile takowe były dostępne, rzadko opatrując je modyfikacjami, co zaznacza w przypisach. Oryginalne przekłady cytatów z greki na język polski są dziełem Marcina Podbielskiego, przekłady zaś cytatów łacińskich opracował sam tłumacz. Książkę ozdabiają ilustracje: 11 podobizn filozofów, w tym mało znane podobizny prawdopodobnie Plotyna z Muzeum w Ostii, oraz rzeźby portretowe z Muzeum w Atenach, a także fotokopie stron tytułowych ważnych publikacji historycznofilozoficznych, dotyczących omawianego autora bądź szkoły. Barwna okładka, podobnie jak w poprzednich tomach Historii filozofii starożytnej, ukazuje fragment Szkoły Ateńskiej Rafaela. Objaśnienie, co do postaci na okładce, znajdzie Czytelnik na ostatniej stronie książki.

Roman Majeran - Lublin

\section{Wincenty MYSZOR, Europa: pierwotne chrześcijaństwo, idee i życie społeczne chrześcijan (II i III w.), Warszawa 1999/2000, Studium Generale Europa, ss. 252.}

Najnowsza książka Wincentego Myszora Europa: pierwotne chrześcijaństwo ukazała się jako siódmy z kolei tom serii „Relectiones”, poświęconej „kulturowym, prawnym, społecznym i teologicznym aspektom integracji euro- 